\title{
PENGARUH PEMBERIAN EKSTRAK ETANOL JAHE MERAH (Zingiber officinale Roxb var Rubrum) TERHADAP JUMLAH SPERMATOGENIK MENCIT (Mus musculus L.) YANG DIINDUKSI SIPROTERON ASETAT
}

\section{EFFECT OF FEEDING RED GINGER ETHANOL EXTRACT (Zingiber officinale Roxb var Rubrum) ON TOTAL SPERMATOGENIC IN MICE (Mus musculus L.) INDUCED BY CYPROTERONE ACETATE}

\author{
Nur Bebi Ulfah Irawati ${ }^{1 *}$, Sutyarso ${ }^{1}$, Hendri Busman ${ }^{1}$ \\ 1Jurusan Biologi FMIPA Universitas Lampung \\ * nurbebiulfah@yahoo.com
}

\begin{abstract}
ABSTRAK
Infertilitas merupakan kondisi yang umum ditemukan dan dapat disebabkan oleh faktor perempuan atau laki-laki, parameter kesuburan dapat dilihat melalui kemampuan spermatozoa yang dihasilkan. Penelitian ini bertujuan untuk mengetahui pengaruh ekstrak etanol jahe merah dalam meningkatkan jumlah spermatogenik mencit(Mus musculus L.) yang diinduksi siproteron asetat. Penelitian ini menggunakan 25 ekor mencit jantan yang dibagi secara acak menjadi 5 kelompok yaitu kontrol normal, dimana hanya akan diberi pakan dan aquades. Kontrol negatif, diberikan siproteron asetat $1,17 \mathrm{mg} / \mathrm{ml}$ secara oral selama 7 hari. Kelompok P1, P2 dan P3 diinduksi siproteron asetat $1,17 \mathrm{mg} / \mathrm{ml}$ secara oral selama 7 hari kemudian diberikan ekstrak etanol jahe merah dengan dosis P1: $6 \mathrm{mg} / \mathrm{ml}, \mathrm{P} 2: 12 \mathrm{mg} / \mathrm{ml}$, dan P3: $24 \mathrm{mg} / \mathrm{ml}$ selama 28 hari. Parameter yang dihitung dan diamati pada penelitian ini adalah jumlah sel spermatogonium, sel spermatosit primer dan sel spermatid mencit jantan. Pengaruh ekstrak terhadap parameter dianalisis dengan Analysis of Varian (ANOVA). Hasil penelitian menunjukkan bahwa ekstrak etanol jahe merah yang diberikan pada dosis yang berbeda dapat meningkatkan jumlah sel spermatogonium, sel spermatosit primer dan sel spermatid mencit jantan yang diinduksi siproteron asetat.
\end{abstract}

Kata kunci: mencit jantan, sel spermatogenik, jahe merah, siproteron asetat

\begin{abstract}
Infertility is a common condition and can be caused by women or men factors. Parameter of fertility can be seen through theability of sperm. This study aimed to know the effect of red ginger ethanol extract in order to increase the number of spermatogenic in mice (Mus musculus L.) induced by cyproterone acetate. This study used 25 male mices which divided randomly into 5 groups which were, normal control (K), negative control (K-), P1, P2 and P3. Normal control only fed with feed and aquadest. Negative control induced by cyproterone acetate $1,17 \mathrm{mg} / \mathrm{ml}$ orally for 7 days. Group of P1, P2 and P3 were induced with cyproterone acetate $1,17 \mathrm{mg} / \mathrm{ml}$ orally for 7 days then fed with red ginger ethanol extract with P1 dose: $6 \mathrm{mg} / \mathrm{ml}, \mathrm{P} 2$ : $12 \mathrm{mg} / \mathrm{ml}$, and P3: $24 \mathrm{mg} / \mathrm{ml}$ for 28 days. Parameters calculated and observed in this study were the number of spermatogonial cells, primary spermatocytes cells and spermatids cells of male mice. Effect of extract parameters was analyzed with Analysis of Variants (ANOVA). The results showed that the red ginger ethanol extract given on different doses can increase the number of spermatogonial cells, primary spermatocytes cells and spermatids cells in cyproterone acetate induced male mice.
\end{abstract}

Keyword: mice, spermatogenic cell, red ginger, cyproterone acetate 


\section{PENDAHULUAN}

Infertilitas merupakan kondisi yang umum ditemukan dan dapat disebabkan oleh faktor baik betina, dan jantan, maupun keduanya. Menurut Hardjopranjoto (1995) kesuburan pada hewan jantan dapat diukur dari kemampuan spermatozoa yang dihasilkan dalam melakukan proses fertilisasi. Proses tersebut dipengaruhi oleh banyak faktor, diantaranya adalah kemampuan organ dan hormon yang mempengaruhi proses reproduksi untuk bekerja secara optimal. Pengoptimalan kerja dari organ dan hormon reproduksi selain dipengaruhi oleh unsur genetik juga dipengaruhi oleh faktor lingkungan. Faktor lingkungan dapat meningkatkan kualitas dan kuantitas spermatozoa yang dihasilkan.

Jahe (Zingiber officinale Roxb.) merupakan salah satu tumbuhan yang berasal dari suku Zingiberaceae. Jahe merah sebagai tumbuhan etnobotani memiliki posisi yang penting dalam berbagai aspek antara lain aspek kesehatan dan perekonomian, aspek kegunaan, adat serta kepercayaan. Jahe banyak digunakan masyarakat sebagai minuman dan bahan makanan, bahan pewarna serta obat-obatan. Zat aktif yang terdapat pada jahe adalah limoen, 1-8 sinoel, 10-dehidrogingerdion, 10-gingerdion, 6gingerdion, 6-gingerol, $\alpha$-asam linolenik, arginin, asam aspartate, $\beta$-sithoserol, asam saprilik, capsaicin, asam klorogenik, farnesol (Hariana, 2002). Zat-zat tersebut mampu mengurangi serta mencegah terbentuknya radikal-radikal bebas. Oleh karena itu, jahe merah dianggap sebagai obat herbal yang aman dengan efek samping yang sangat minimal. Hasil dari aktivitas antioksidan, jahe akan memacu aktivitas androgenik untuk organ testis melalui peningkatan hormon $\mathrm{LH}$, FSH, dan testosteron (Ali et al., 2008).

Siproteron asetat merupakan salah satu obat golongan antiandrogen yang dapat menginduksi terjadinya infertilitas pada pria. Pada penelitian ini siproteron asetat merupakan obat yang digunakan untuk menginduksi hewan uji menjadi infertil.

\section{METODE}

Penelitian ini menggunakan 25 ekor mencit jantan dengan berat badan berkisar $25-30$ g/ekor. Metode yang digunakan adalah Rancangan Acak Lengkap (RAL) dengan 5 kelompok yaitu kontrol normal (K), kontrol negatif ( $K-), P 1, P 2$, dan P3 yang berlangsung selama 35 hari (lama siklus spermatogenik mencit) dengan pengulangan sebanyak 5 kali. Kontrol normal, hanya diberi pakan dan aquades. Kontrol negatif, diinduksi siproteron asetat $1,17 \mathrm{mg}$ secara oral selama 7 hari . Kelompok P1, P2 dan P3 diinduksi siproteron asetat $1,17 \mathrm{mg}$ secara oral selama 7 hari bertuturt-turut selanjutnya diberikan ekstrak etanol jahe merah dengan dosis $\mathrm{P} 1: 6 \mathrm{mg} / \mathrm{ml}$, P2: $12 \mathrm{mg} / \mathrm{ml}$, and P3: $24 \mathrm{mg} / \mathrm{ml}$ selama 28 hari. Pembedahan dilakukan setelah 35 hari perlakuan untuk pengambilan organ testis, selanjutnya dilakukan pembuatan preparat histologi testis.

Pengawetan jaringan dan pembuatan preparat terdiri dari proses trimming, dehidrasi, clearing, impregnasi,dan embedding. Trimming menggunakan formalin $10 \%$ untuk fiksasi testis. Dehidrasi menggunakan alkohol $70 \%$, $80 \%, 90 \%, 96 \%$, dan alkohol absolut untuk menarik air dari sediaan. Clearing menggunakan xylol untuk menarik alkohol 
kembali. Impregnasi (infiltrasi parafin) dan embedding (pengeblokan jaringan) menggunakan parafin selanjutnya dilakukan pemotongan jaringan menggunakan mikrotom putar dengan ketebalan $4 \mu \mathrm{m}$. Pewarnaan menggunakan Hematoxylin Eosin. Penempelan jaringan dan cover glass pada object glass menggunakan canada balsam. Perhitungan dilakukan dengan mengamati preparat histologi dari irisan testis menggunakan mikroskop dengan perbesaran 400x.

Parameter yang dilihat pada penelitian ini adalah sel spermatogonium, sel spermatosit primer dan sel spermatid. Data dianalisis dengan menggunakan Analysis of Variance (ANOVA) untukmengetahui ada tidaknya perbedaan antar perlakuan. Apabila terdapat perbedaan yangnyata maka dilanjutkan dengan uji beda nyata terkecil (BNT) pada taraf $5 \%$.

\section{HASIL}

Data hasil penelitian rerata jumlah sel spermatogenik mencit jantan pada sel spermatogonium menunjukkan bahwa kelompok kontrol negatif memiliki rerata jumlah sel spermatogonium paling rendah sedangkan kelompok P3 memiliki rerata jumlah sel spermatogonium paling tinggi.

Berdasarkan data penelitian rerata jumlah sel spermatosit primer, terdapat penurunan rerata jumlah sel spermatosit primer mencit jantan pada kelompok kontrol negatif dibandingkan dengan kontrol normal, selanjutnya terjadi peningkatan kembali pada kelompok P1, P2 dan P3. Kelompok P3 memliki rerata tertinggi dibandingkan kelompok lainnya sedangkan kelompok kontrol negatif memiliki rerata paling rendah.

Data hasil penelitian rerata jumlah sel spermatid pada kontrol normal terhadap kontrol negatif mengalami penurunan, selanjutnya terdapat peningkatan rerata jumlah sel spermatid pada kelompok perlakuan (P1, P2 dan P3) terhadap kontrol negatif. Pada rerata kelompok 3 memiliki rerata tertinggi dan melebihi kelompok normal dibandingkan kelompok perlakuan lainnya yaitu P1 dan P2.

Uji Anova memberikan hasil yang signifikan secara statistik terhadap rerata jumlah sel spermatogonium mencit jantan dan dilanjutkan uji BNT. Hasil uji lanjut menunjukkan adanya perbedaan bermakna pada kelompok kontrol normal terhadap kelompok kontrol negatif dan kelompok kontrol normal terhadap kelompok P3, selanjutnya pada kelompok kontrol negatif terhadap kelompok perlakuan (P1, P2 dan P3). Perbedaan tidak bermakna terdapat pada kelompok normal terhadap kelompok P1 dan $\mathrm{P} 2$, lalu pada kelompok P1 terhadap kelompok P2 dan P3, serta pada kelompok P2 terhadap kelompok P3. (Gambar 1)

\section{Rerata Jumlah Sel Sermatogonium}

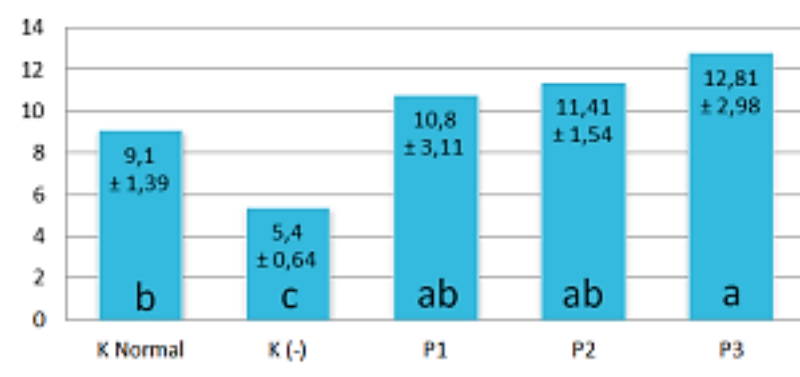

= Keterangan: Kontral Normal (K), Kontrol Negatif (K-) 6mgiml (P1), 12mg/ml (P2), 24mgiml (P3) Angka yang dikuti huruf superskrip beibeda menunjukkan beda nyata berdasarkan uji BNT taraf 5\%.

Gambar 1. Rerata jumlah sel spermatogonium mencit jantan (sel/lapang pandang) tiap kelompok perlakuan. 
Uji Anova memberikan hasil yang signifikan secara statistik terhadap rerata jumlah sel spermatosit primer mencit jantan dan dilanjutkan uji BNT. Hasil uji lanjut menunjukkan adanya perbedaan bermakna pada kelompok kontrol normal terhadap kelompok kontrol negatif, kelompok P1 dan kelompok P2, selanjutnya perbedaan bermakna juga didapatkan pada kelompok kontrol negatif terhadap kelompok P3. Perbedaan tidak bermakna didapatkan pada kelompok normal terhadap kelompok P3, kelompok kontrol negatif terhadap kelompok $\mathrm{P} 1$ dan P2, kelompok P1 terhadap kelompok P2. (Gambar 2)

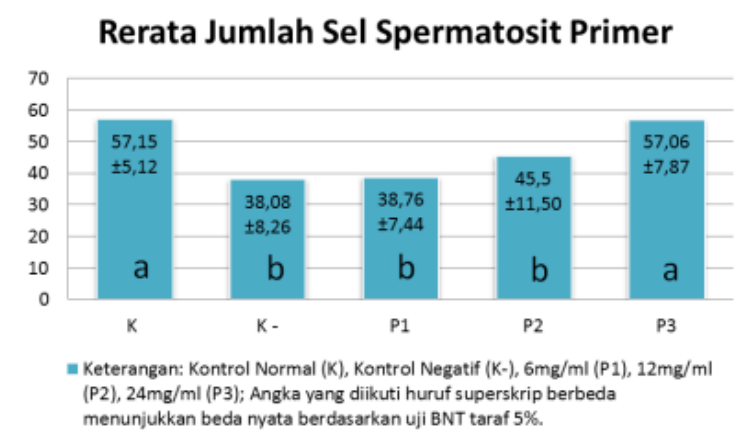

Gambar 2. Rerata jumlah sel spermatosit primer mencit jantan (sel/lapang pandang) tiap kelompok perlakuan.

Uji Anova memberikan hasil yang signifikan secara statistik terhadap rerata jumlah sel spermatid mencit jantan dan dilanjutkan uji BNT. Berdasarkan hasil uji lanjut didapatkan perbedaan bermakna pada kelompok normal terhadap kelompok kontrol negatif, lalu pada kelompok kontrol negatif terhadap kelompok P3. Perbedaan tidak bermakna terdapat pada kontol normal terhadap kelompok perlakuan P1, P2 dan P3 selanjutnya pada kelompok kontrol negatif terhadap kelompok P1 dan P2, kelompok P1 terhadap P2 dan P3, kelompok P2 terhadap P3. (Gambar 3)

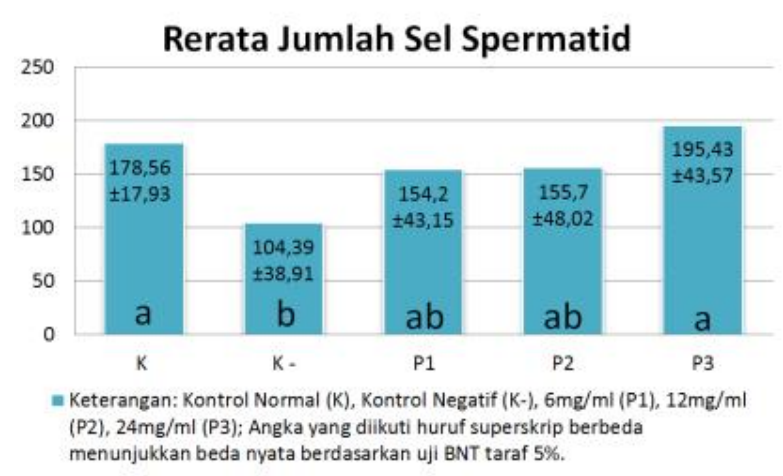

Gambar 3. Rerata jumlah sel spermatid mencit jantan (sel/lapang pandang) tiap kelompok perlakuan.

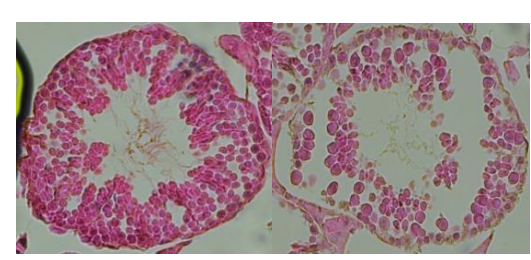

(1)

(2)

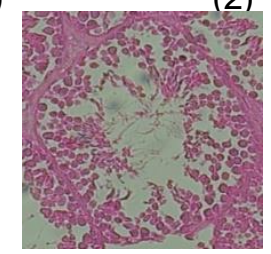

(3)

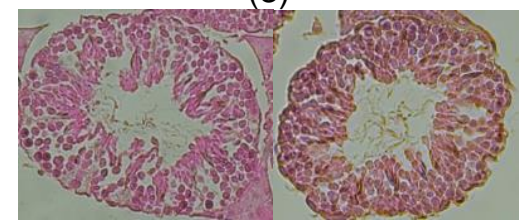

(4)

(5)

Gambar 4. Penampang melintang tubulus seminiferus mencit jantan pada tiap kelompok (Keterangan : 1) Kontrol Normal; 2) Kontrol Negatif; 3) Perlakuan 1; 4) Perlakuan 2; 5) Perlakuan 3).

Pada Gambar 4 kelompok kontrol normal terlihat dalam keadaan baik, sel-sel spermatogenik tampak tersusun rapih, meliputi spermatogonium, spermatosit primer, spermatosit sekunder, spermatid dan spermatozoa. Pada kelompok kontrol negatif terlihat penurunan jumlah sel spermatogenik dan susunan sel-sel spermatogenik tidak beraturan. Pada kelompok perlakuan 1 terjadi 
peningkatan jumlah sel-sel spermatogenik dibandingkan kelompok kontrol negatif, namun sel-sel belum tersusun secara baik seperti kontrol normal. Pada kelompok perlakuan 2 sel-sel spermatogenik terlihat lebih rapih dan tersusun dibandingkan kelompok perlakuan 1. Kepadatan sel-sel spermatogenik terlihat cenderung hampir sama dengan kelompok kontrol normal. Pada kelompok 3 (Gambar $9 . e)$, terlihat adanya peningkatan jumlah selsel spermatogenik pada tubulus seminiferus.

\section{PEMBAHASAN}

Berdasarkan hasil penelitian dan analisis data, pemberian ekstrak etanol jahe merah mempunyai pengaruh yang bermakna secara statistik pada peningkatan jumlah sel spermatogonium, sel spermatosit primer dan sel spermatid. Hal ini sesuai dengan penelitian Khaki (2009), pemberian ekstrak jahe dengan dosis $50 \mathrm{mg} / \mathrm{kgBB}$ dan $100 \mathrm{mg} / \mathrm{kgBB}$ selama 20 hari sudah memberikan pengaruh positif terhadap sistem reproduksi tikus putih jantan.

Hasil penelitian Kikuzaki dan Nakatani (1993) menunjukkan bahwa jahe (Zingiber officinale. Roxb.) memiliki senyawa aktif fenolik seperti gingerol, shagaol, zingeron, gingerdiol dan zingiberen yang terbukti memiliki aktivitas antioksidan.Jahe juga dilaporkan memiliki androgenik karena mampu meningkatkan konsentrasi hormon testosterone dalam serum (Kamtchouing et al., 2002). Hormon testosterone berfungsi untuk mengontrol proses spermatogenik, memelihara sel sertoli dan berperan dalam menentukan kualitas spermatozoa.Pada penelitian yang dilakukan oleh Morakinyo A. O dkk. (2008), pemberian ekstrak jahe merah terhadap tikus jantan dewasa dengan dosis $500 \mathrm{mg} / \mathrm{kgBB}$ dan
$1000 \mathrm{mg} / \mathrm{kgBB}$ selama 14 hari dan 28 hari didapatkan bahwa jahe merah memiliki pengaruh positif pada fungsi reproduksi tikus dewasa jantan. Pengaruh tersebut berupa peningkatan jumlah dan motilitas sperma, jumlah testosteron, dan penurunan level malonhydialdehyde.

Pada penelitian ini terdapat penurunan jumlah sel spermatogenik pada kelompok kontrol negatif disebabkan induksi siproteron asetat yang menghasilkan radikal bebas berupa antiandrogen yang dapat menghambat proses spermatogenesis dan merusak struktur spematozoa. Radikal bebas menyebabkan karsinogen dan toksisitas pada kulit dan organ reproduksi. Radikal bebas juga dapat menyebabkan menurunnya produksi hormon $\mathrm{LH}$ dan FSH yang merangsang terbentuknya hormon testosteron. Hal ini mengakibatkan jumlah testosteron menurun dan akhirnya spermatogenesis pun ikut terhambat (Mostafa, 2010).

Penggunaan siproteron asetat pada pria menyebabkan perlu adanya pengganti hormon androgen akibat efek antiandrogen pada siproteron asetat. Siproteron asetat menyebabkan penurunan sel spermatogenik yang disebabkan oleh efek langsungnya terhadap testis dimana siproteron asetat menghambat ikatan antara testosterone dan dehidrotestosteron dengan reseptor androgennya (Rajalakshmi, 2005).

\section{SIMPULAN}

Dari hasil penelitian yang dilakukan, pemberian ekstrak etanol jahemerah memicu peningkatan jumlah sel-sel spermatogenik berupa sel-sel spermatogonium, sel-sel spermatosit dan sel-sel spermatid mencit 
jantan pasca diinduksi siproteron asetat meningkat.

\section{DAFTAR PUSTAKA}

Ali, B.H., Blunden, G., Tanira, M.O. dan Nemmar, A. 2008. SomePhytochemical, Pharmacological and Toxicological Properties of Ginger (Zingiber officinale Roscoe): a review of recent research. Food Chem Toxicol (46) 409-420.

Hardjopranjoto, S. 1995. IImu Kemajiran pada Ternak. Airlangga University Press. Surabaya.

Hariana, H.A. 2002.Tumbuhan Obat dan Khasiatnya, Penebar Swadaya, Jakarta.

Hestiantoro, A. dan Soebijanto, S. 2013.

Konsensus Penanganan Infertilitas.HIFERI.Jakarta.

Kamtchouing, P., Mbongue, G.Y., Dimo, T. dan Jatsa, H.B. Evaluation of androgenic activity of Zingiber officinale and Pentadiplandra brazzeana in male rats. Asian J. Androl. 2002; 4(4): 299.

Khaki, A., Fathiazad F., Nouri M., Khaki AA., Ozanci CC., Novin MG., dkk. 2009. The Effect of ginger on spermatogenesis and sperm parameters of rat. Iranian Journal of Reproductive Medicine (7) (1) pp 7 12.

Kikuzaki dan Nakatani. 1993. Antioxidant effects of some ginger constituents. $J$ Food Sci. 58(6) 1407.

Morakinyo, A.O., Adeniyi, O.S. dan Arikawe, A.P. 2008. Effect of zingiber officinale on reproductive function in the male rats. African Journal of Biomedica Research. Vol.11: 329-334.

Mostafa, T. 2010. Cigarette Smoking and Male Infertility. Journal of Advanced Research. (1) hal 179-196.

Rajalakshmi, M. 2002. Male contraception: expanding reproductive choice. India Institute of Medical Science. Indian J. Experimantal Biology. 43 pp 1032-1041. 